\author{
Case Study
}

\title{
AYURVEDIC MANAGEMENT OF ATOPIC DERMATITIS BY RAKTAMOKSHAN (WET CUPPING): A CASE REPORT
}

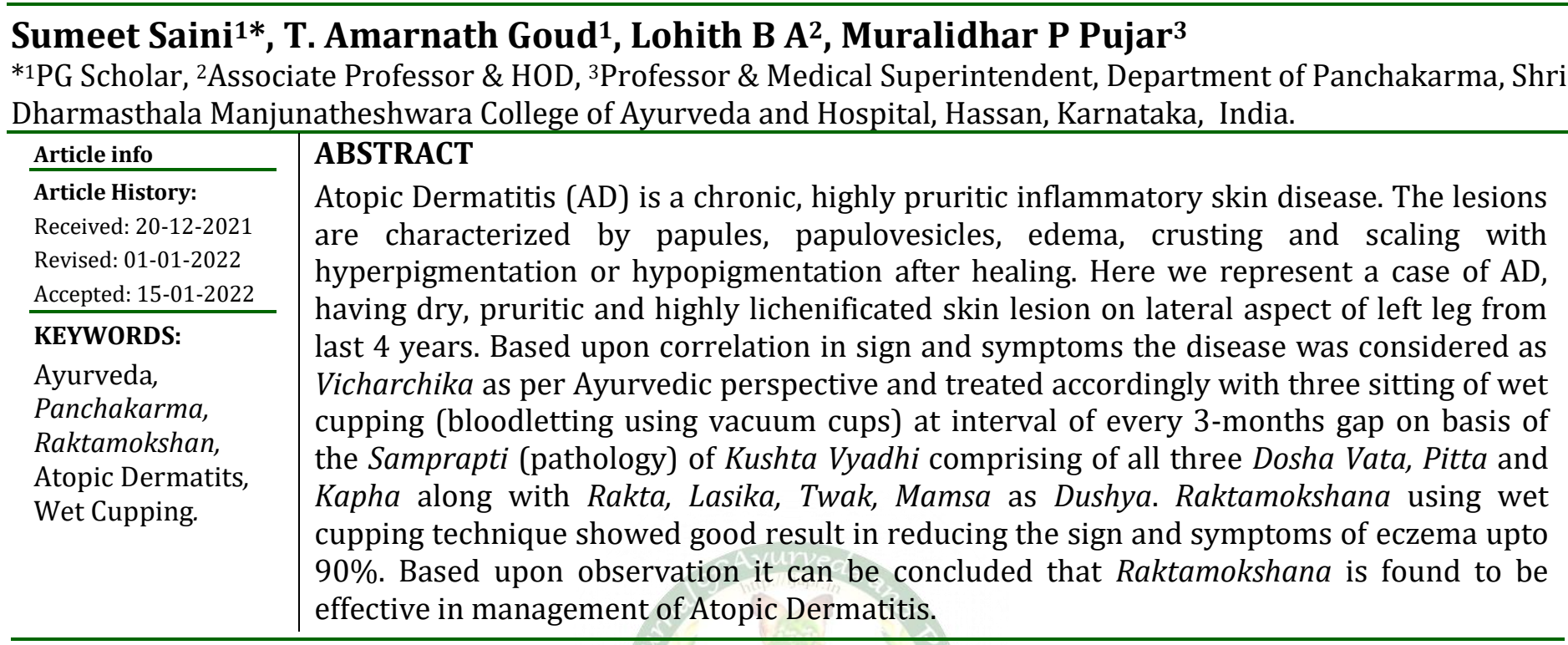

\section{INTRODUCTION}

Atopic Dermatitis (AD), also known as eczema and atopic eczema, is a type of inflammatory skin disease that affects up to $20 \%$ of children and $10 \%$ of adults ${ }^{[1]}$. AD is a chronic, highly pruritic (itchy) inflammatory skin disease ${ }^{[2]}$. The lesions are characterized by papules, papulovesicles, edema, crusting, and scaling, with hyperpigmentation or hypopigmentation of lesions after healing. Pruritus is a hallmark of atopic dermatitis, and the intensity of the itching broadly corresponds to the severity of the disease. Pruritus is aggravated by stress, sweating from physical activity or environmental heat, and humidity, as well as from contact with woolen clothes ${ }^{[3]}$. Pruritus-related scratching induces excoriations, bleeding, or the formation of hemorrhagic crusts. Persistent scratching leads to lichenification.

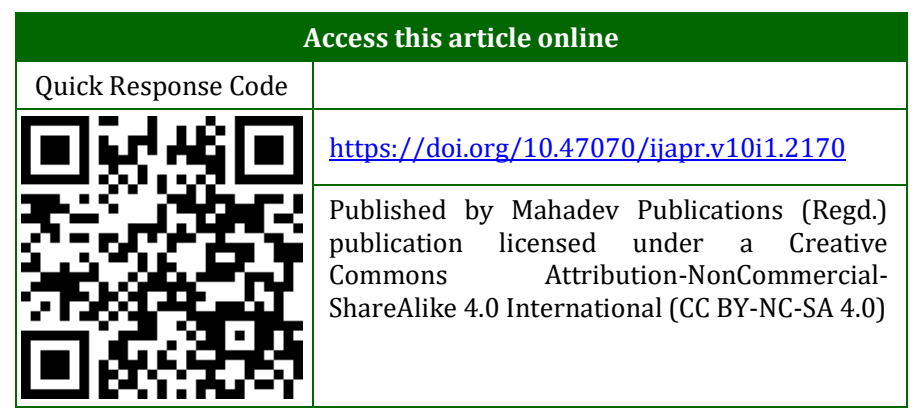

Management of $\mathrm{AD}$ requires a multifaceted approach that involves patient and caregiver education, optimal skin care practices, antiinflammatory treatment with topical corticosteroids (first-line) and/or Topical Calcineurin Inhibitors (TCIs), and the treatment of skin infections. Systemic immunosuppressive agents may also be considered in severe cases that cannot be controlled with appropriate skin care and topical therapy ${ }^{[2]}$. But due to complication associated with use of steroids and despite use of medicines, relapse is a concern, so alternative approach for the treatment of $\mathrm{AD}$ is required. In Ayurvedic texts, for skin diseases Rakta Dushti is considered as one of the cause ${ }^{[4]}$. Acharya Sushruta considered Rakta as fourth Dosha[5] along with Vata, Pitta and Kapha dosha and considered Raktamokshan (bloodletting) as one among the Pancha Shodhan procedures and explained various methods of Raktamokshana such as Jalaukavacharana, Shrunga, Alabu, Prachhanna Karma, and Siravedhana Karma[6] based upon different Dosha predominance and the area involved. Here use of wet cupping, a modified type of bloodletting procedure for the treatment of eczema.

\section{Patient Information}

A 24-year female patient from last 4 years, having dry, pruritic and highly lichenificated skin lesion on lateral aspect of left leg not having any 
history of diabetes, hypertension or any systemic abnormality no any family history for the same condition, for which patient had consulted many physicians of contemporary science and taken antibiotics, steroids and judicious use of topical antiinflammatory agents and topical emollients, but didn't get satisfactory result as after stopping the medicine the symptoms reappeared so patient consulted in OutPatient Department of Panchakarma at Shri Dharmasthala Manjunatheshwara college of Ayurveda and hospital, Hassan for further management.

\section{Clinical Findings}

Patient was not having symptoms 4 -year back but gradually started having hyperpigmentation on lateral aspect of left lower limb associated with intense itching which started spreading but remain confined below knee joint with appearance of dry, pruritic, lichenification and erythematous lesions showing similarity with Vicharchika having Lakshan of Shayav Pidika (redness and pustules), Atikandu (itching), Bahusraav (profused discharge) and Rukshta (roughness)[7]. On examination, patient had moderate appetite, Krurkoshta (hard stools with regular micturition), uncoated tongue. Patient is Vatapitta prakriti with Madhyam Sara (medium body built), Sama Pramana (normal body proportion), Madhyam Satmya (homologation), Pravara Satva (good mental strength), Avara Vyayamshakti (least capability to carry on physical activities), Madhyam Aharshakti and Jaranshakti (medium food intake and digestive power).

Timeline: Timeline of case have been listed in table 1 .

Table 1: Showing Timeline of Cases

\begin{tabular}{|l|l|}
\hline Date & Clinical intervention \\
\hline September 2017 & $\begin{array}{l}\text { Appearance of scaly lesion on } \\
\text { left lower limb }\end{array}$ \\
\hline $2017-2021$ & $\begin{array}{l}\text { Consulted various physicians } \\
\text { and took allopathic medicine } \\
\text { but no satisfactory outcome }\end{array}$ \\
\hline 7 March 2021 & First sitting of wet cupping \\
\hline
\end{tabular}

\begin{tabular}{|l|l|}
\hline 4 June 2021 & Second sitting of wet cupping \\
\hline 8 September 2021 & Third sitting of wet cupping \\
\hline
\end{tabular}

\section{Diagnostic Focus and Assessment}

In Ayurveda for Kushta various treatment modalities have been mentioned depending upon Doshic condition as Sarpipana, Vamana, Virechana and Raktamokshana in Vata, Kapha, Pitta and Rakta dushti respectively[8]. Based upon clinical presentation of the patient, localized lesion confined only to left leg. Wet cupping was performed and assessed before and after every sitting of Wet cupping.

\section{Therapeutical Intervention}

After proper examination the case was treated on day care basis with Ayurvedic line of treatment using wet cupping technique of Raktamokshana, for three subsequent sitting with interval of 3-months gap. The line of treatment was selected as Raktamokshana as skin lesion was localized and dry in nature with excessive itching indicating more of Vata dosha predominance so wet cupping was selected as the procedure of choice as the action of wet cupping have more of similarity with Shrunga type of Raktamokshana indicated mainly in Vata Dosha. The procedure was performed under aseptic condition using needle of 18G and cups (area to be treated was cleaned using spirit swap followed by application of cup creating vacuum by mean of negative pressure to create transient hyperemic state then superficial pricks were made using $18 \mathrm{G}$ needle in linear manner again application of cup with negative pressure so that to extract blood from superficial layer of skin, post procedure blood was cleaned and application of honey for healing of scar for 3 days) as mentioned in table no 1. No internal medicine was administered during the course of treatment.

\section{Follow-Up and Outcomes}

After 3 sittings of Wet cupping patient showed significant results in treating the patient condition as showed in figures below (1-3).

Figure 1: Before treatment
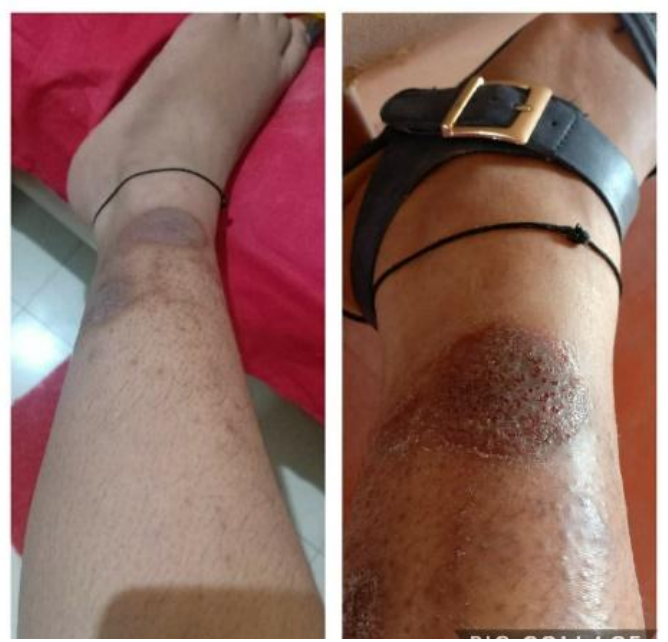
Figure 2: Showing procedure of wet cupping and after $1^{\text {st }}$ sitting of Wet cupping
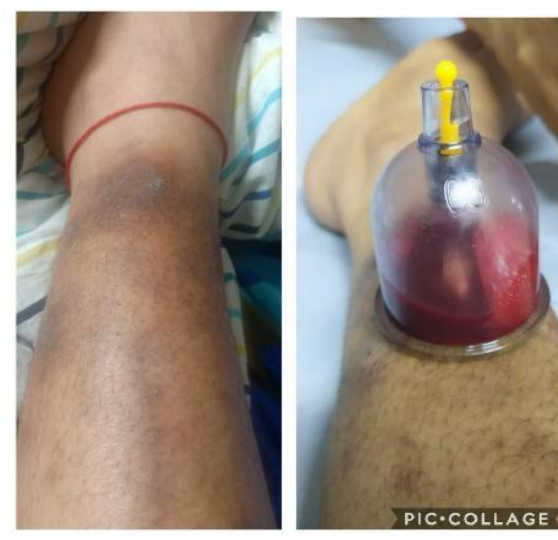

Figure 3: After 2nd and 3rd sitting of Wet cupping

\section{DISCUSSION}

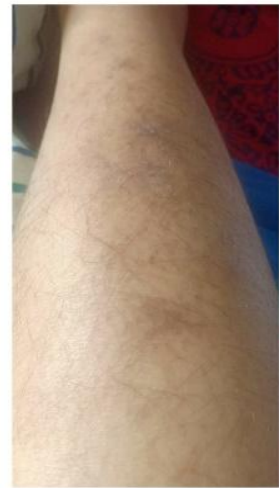

Symptoms of Atopic dermatitis can be compared with Lakshans of Vickharchika as Shayav Pidika, Atikandu, Bahusraav and Rukshta. As Kushta is a Chirkari Vyadhi for which repetitive Shodhana have been indicated[9]. According to Acharya Sushruta for Kushta chikitsa, Vamana can be repeated at interval of every 15 days, Virechana at interval of 30 days, Raktamokshan after every 6 months[10]. Kushta is one among the Raktapradoshaj Vyadhi, ${ }^{[11]}$ so bloodletting is one of the prime methods of treatment for treating skin condition where all other treatment modalities fails[12]. According to Acharya Sharangdhara, maximum amount of blood can be withdrawn at one time depend upon the Bala of Roga (disease) and Rogi (patient) up to $648 \mathrm{ml}, 324$ and $162 \mathrm{ml}$ at once in case to maximum, minimum and least strength[13]. As the quantity of blood withdrawn (around 25-30ml) is much less than the minimum quantity of blood which can be withdrawn in single sitting so instead of 6-month interval we adopted the treatment interval of 3-month gap. Various methods of bloodletting have been explained depending upon Dosha and site involved as described in table no 2 below [14]. In Bahu Dosha (more of disease causing factor) condition Shodhana such as Vaman and Virechana is mainly indicated but in this case as the lesion was localized at one place and having more of Vata dosha symptoms so Sthanika chikitsa as wet cupping was selected as the line of treatment.

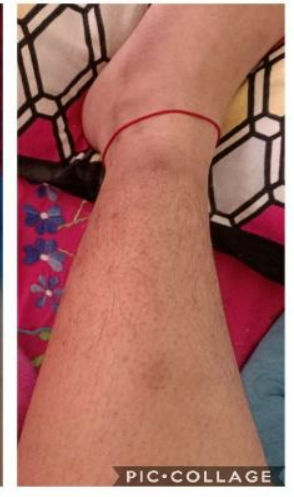

Table 2: Different Types of Raktamokshana and Their Indication

\begin{tabular}{|l|l|l|}
\hline $\begin{array}{l}\text { Method of } \\
\text { Raktamokshan }\end{array}$ & $\begin{array}{l}\text { Dosha } \\
\text { involved }\end{array}$ & Therapeutic action \\
\hline Shrunga & Vata & 10 Angula \\
\hline Alabu & Kapha & 12 Angula \\
\hline Jalaouka & Pitta & 1 Hastha (24 Angula) \\
\hline Siravedha & Tridosha & $\begin{array}{l}\text { Sarva Sharir (full } \\
\text { body) }\end{array}$ \\
\hline Prachan & Tridosha & 1 Angula \\
\hline
\end{tabular}

\section{CONCLUSION}

Hence we can conclude that Ayurveda treatment had proved to be effective in treating skin disease with fewer side effects. Hence, based upon condition as localized skin lesion was present so wet cupping line of treatment can be taken into consideration for treatment of Atopic Dermatitis but a lot of further study is needed.

\section{REFERENCES}

1. Langan, Sinéad M et.al. Atopic Dermatitis, The Lancet, Volume 396, Issue 10247, 345 - 360.

2. Kapur, S., Watson, W., \& Carr, S. (2018). Atopic dermatitis. Allergy, asthma, and clinical immunology: official journal of the Canadian Society of Allergy and Clinical Immunology, 14 (Suppl 2), 52. 
3. Ständer, Sonja, Atopic Dermatitis; New England Journal of Medicine March 25, 2021384 (12): 1136.

4. Dr.Harishchandra Singh Kushwaha, editor. Commentary Agnivesha of Charaka Samhita, Sutra Sthana. Vidhishonitya Adhyaya Chapter 24, Verse 16. Varanasi: Chaukhambha Orientalia, 2018. p. 333.

5. Dr.Kewal krishan thakaral, editor. Commentary Dhalana and Gayadas of Sushruta Samhita, Chikitsa sthana. Netrabasti praman pravibhag chikitsitam vyakhayam chapter 35, Verse 6. Varanasi: Chaukhambha Orientalia, 2019. p. 528. Sushruta sutra $21 / 3$

6. Dr.Kewal krishan thakaral, editor. Commentary Dhalana and Gayadas of Sushruta Samhita, Sutrasthana. chapter 13, Verse 4. Varanasi: Chaukhambha Orientalia, 2019. p. 131.

7. Dr.Harishchandra Singh Kushwaha, editor. Commentary Agnivesha of Charaka Samhita, Sutra Sthana. Kushtachikitsa Adhyaya Chapter 7, Verse 26. Varanasi: Chaukhambha Orientalia, 2018. p. 199.

8. Dr.Harishchandra Singh Kushwaha, editor. Commentary Agnivesha of Charaka Samhita, Chikitsa Sthana. Kushtachikitsa Adhyaya Chapter 7, Verse 39. Varanasi: Chaukhambha Orientalia, 2018. p. 201.

9. Dr.Harishchandra Singh Kushwaha, editor. Commentary Agnivesha of Charaka Samhita,

Cite this article as:

Sumeet Saini, T. Amarnath Goud, Lohith B A, Muralidhar P Pujar. Ayurvedic Management of Atopic Dermatitis by Raktamokshan (Wet Cupping): A Case Report. International Journal of Ayurveda and Pharma Research. 2022;10(1):28-31. https://doi.org/10.47070/ijapr.v10i1.2170 Source of support: Nil, Conflict of interest: None Declared
Chikitsa Sthana. kushtachikitsa Adhyaya Chapter 7, Verse 42. Varanasi: Chaukhambha Orientalia, 2018. p. 201.

10. Dr.Kewal krishan thakaral, editor. Commentary Dhalana and Gayadas of Sushruta Samhita, Chikitsa sthana. kushta chikitsitam vyakhayam chapter 9, Verse 43. Varanasi: Chaukhambha Orientalia, 2019. p. 305.

11. Dr.Harishchandra Singh Kushwaha, editor. Commentary Agnivesha of Charaka Samhita, Sutra Sthana. Vividhashitapitiya Adhyaya Chapter 28, Verse 11. Varanasi: Chaukhambha Orientalia, 2018. p. 475.

12. Dr.Harishchandra Singh Kushwaha, editor. Commentary Agnivesha of Charaka Samhita, Sutra Sthana. Vidhishonitayam Adhyaya Chapter 24, Verse 17. Varanasi: Chaukhambha Orientalia, 2018. p. 333.

13. Dr.Brahmanand Tripathi, Sarangadhara Samhita of Pandit Sarandharacarya, uttarkhanda. Shonitstrav Adhyaya Chapter 12, Verse 1. Varanasi: Chaukhamba Subharti Prakashan, 2021. p. 272.

14. Dr.Brahmanand Tripathi, Sarangadhara Samhita of Pandit Sarandharacarya, Uttarkhanda. Shonitstrav Adhyaya Chapter 12, Verse 25-26. Varanasi: Chaukhamba Subharti Prakashan, 2021. p. 274.

\section{*Address for correspondence Dr. Sumeet Saini \\ PG Scholar, \\ Department of Panchakarma, Shri Dharmasthala \\ Manjunatheshwara College of Ayurveda and Hospital, \\ Hassan, Karnataka, India. \\ Email: drsumeetsaini1@gmail.com}

Disclaimer: IJAPR is solely owned by Mahadev Publications - dedicated to publish quality research, while every effort has been taken to verify the accuracy of the content published in our Journal. IJAPR cannot accept any responsibility or liability for the articles content which are published. The views expressed in articles by our contributing authors are not necessarily those of IJAPR editor or editorial board members. 